Corporate Social Responsibility and its impact on Customer Perception \& Loyalty

Dr. Ashraf Saber Kamel

\title{
Corporate Social Responsibility and its impact on Customer Perception \& Loyalty
}

\author{
Dr. Ashraf Saber Kamel
}

$\mathrm{PhD}$ in Management

\begin{abstract}
The concept of business ethics began in the 1960s as corporations became more aware of a rising consumer-based society that showed concerns regarding the environment, social causes, and corporate responsibility. The increased focus on socalled social issues was a hallmark of the decade.
\end{abstract}

Since that time period, the concept of business ethics has evolved. Business ethics goes beyond just a moral code of right and wrong; it attempts to reconcile what companies must do legally versus maintaining a competitive advantage over other businesses. Firms display business ethics in several ways.

Business ethics refers to implementing appropriate business policies and practices with regard to arguably controversial subjects. Business ethics are supposed to ensure a certain level of trust between consumers and corporations, guaranteeing the public fair and equal treatment. 
Corporate Social Responsibility and its impact on Customer Perception \& Loyalty Dr. Ashraf Saber Kame1

This article attempts to analyze the impact of one of the most significant \& crucial aspects of business ethics; Corporate Social Responsibility, and elaborates its effects on consumers' behavior as well as employees.

Keywords: Business ethics, Corporate Social Responsibility, Business Practices, Competitive Advantage.

\section{Introduction}

Corporate social responsibility (CSR) is a self-regulating business model that helps a company be socially accountable to itself, its stakeholders, and the public. According to The Financial Times, corporate social responsibility is "a business approach that contributes to sustainable development by delivering economic, social and environmental benefits for all stakeholders".

By practicing corporate social responsibility, also called corporate citizenship, companies can be conscious of the kind of impact they are having on all aspects of society including economic, social, and environmental. (Chen, James 2019)

To engage in CSR means that, in the normal course of business, a company is operating in ways that are beneficial \& enhance 
Corporate Social Responsibility and its impact on Customer Perception \& Loyalty

Dr. Ashraf Saber Kamel

society and the environment, instead of contributing negatively to them. (Chen, James 2019)

Corporate Social Responsibility is a broad term used to describe a company's effort to assist \& improve the society in some way. The European Commission defined CSR as "the responsibility of enterprises for their impacts on society"

Corporate social responsibility (CSR) has become one of the standard business practices of our time. Organizations tend to engage in CSR activities for maintaining a good public image and enhanced overall reputation. In many countries, implementation of CSR isn't mandatory however it is considered as an "extra mile" that corporates \& organizations practice in order to stand out in their consumers' perspectives.

For Corporations, engaging in CSR refers to having a positive impact on the society. This is achieved by exerting efforts including: monetary \& product donations, project funding, implementing environment- friendly policies, volunteerism etc.

CSR is one of the keys to long range business success as it assists in building a large base of loyal customers \& stakeholders. A company's ethical behavior and CSR efforts may improve its positive image and reputation in the marketplace.

Companies or corporations are facing increasing demands that, they look beyond their own interests and prioritize those of the

العدد الأول الجزء الأول •.r.

المجلد الحادي عشر 
Corporate Social Responsibility and its impact on Customer Perception \& Loyalty Dr. Ashraf Saber Kame1

societies in which they operate (Broomhill, 2007). The notion that, business enterprises have responsibilities to society beyond that of making profits for shareholders has been around for centuries (Carroll, \& Shabana, 2010).

Therefore, this study's main aim is to identify the extent to which CSR affects customer perception, loyalty, and employee relationship towards the organization.

\section{Research Hypothesis:}

The ultimate objective of this study is to analyze the role of CSR in terms of affecting customer perception; therefore, the study is conducted to affirm and substantiate the following assumptions.

The study's main hypothesis, H1 advocates that CSR is crucial and has a tremendous impact on the organization's reputation as well as its role in the society. In addition, engaging in CSR adversely impacts the organization's performance through affecting customer perception and positively affecting consumers' behavior.

The study's second hypothesis, H2 supports that employees' performance and tendency to perform tasks effectively is highly impacted by the organizations' CSR efforts. Moreover, CSR

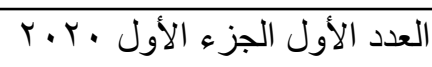

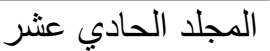


Corporate Social Responsibility and its impact on Customer Perception \& Loyalty Dr. Ashraf Saber Kame1

positively impacts employee loyalty and trust towards the organization.

H1: Corporates \& Organizations that engage in CSR more frequently tend to gain customer trust \& loyalty, as well as improving their reputation in the market.

H2: Organizations that adopt CSR programs tend to perform better in terms of persuading highly qualified \& talented personnel, employee performance, as well as building mutual trust between the corporate and the employee.

\section{Literature Review:}

Organizations that adopt CSR programs are believed to have grown \& expanded in their business to the point where they can give back to society. CSR is primarily a strategy or an act of large corporations. This means that the more visible and successful a corporation is, the more responsibility it has to set standards of ethical behavior for its peers, competitors, and industry.

According to the United Nations Industrial Development Organization (UNIDO), Corporate Social Responsibility is a management concept whereby companies integrate social and environmental concerns in their business operations and

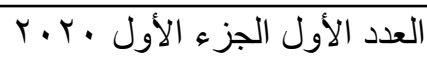

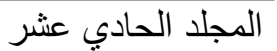


Corporate Social Responsibility and its impact on Customer Perception \& Loyalty Dr. Ashraf Saber Kamel

interactions with their stakeholders. CSR is basically a strategy through which an organization achieves a balance of economic, environmental and social imperatives, while at the same time addressing the expectations of shareholders and stakeholders. (UNIDO: Defining CSR)

CSR aims to ensure that companies conduct their business in a way that is ethical \& beneficial to the surrounding society. This means taking account of their social, economic and environmental impact, and consideration of human rights.

CSR can involve a wide range of programs and activities including: Environmental protection and sustainability, ecoefficiency, labor standards and working conditions, antidiscrimination policies, social equity, human rights, and anticorruption measures.

A properly implemented CSR concept can bring along a variety of competitive advantages, such as enhanced access to capital and markets, increased sales and profits, operational cost savings, improved productivity and quality, efficient human resource base, improved brand image and reputation, enhanced customer loyalty, better decision making and risk management processes. (UNIDO: What is CSR?)

As the business environment gets increasingly complex and stakeholders become vocal about their expectations, good CSR

العدد الأول الجزء الأول •r.r المجلد الحادي عشر 
Corporate Social Responsibility and its impact on Customer Perception \& Loyalty

Dr. Ashraf Saber Kame1

practices can only bring in greater benefits. Undertaking CSR initiatives and being socially responsible can have the following benefits: strengthening relationships with stakeholders; attracting the best industry talents; and risk mitigation because of an effective corporate governance framework (Porter \& Kramer, 2006).

Furthermore, a well-executed CSR program creates social and environmental value, while supporting a company's business objectives and reducing operating costs, and enhancing relationships with key stakeholders and customers (Rangan, Chase, \& Karim, 2012).

Many corporates and organizations are encouraging diversity in the workplace \& embracing individuals of all races, cultures, genders, disabilities and sexual orientations. Moreover, other corporates have implemented CSR strategies such as reducing their carbon footprints, minimizing pollution, raising awareness regarding environmentally friendly alternatives etc.

In the last decade, companies in Egypt began to understand the significance of executing CSR programs; a remarkable example of this is Orange Group Corporation; they have managed to engage in several CSR activities including organizing competitions for innovative entrepreneurship projects, women empowerment, partnering with national and international NGOs and focus groups in several fields such as

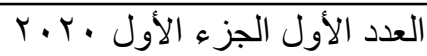

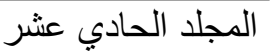


Corporate Social Responsibility and its impact on Customer Perception \& Loyalty Dr. Ashraf Saber Kame1

fighting common ailments including diabetes and cancer, supporting better nutrition, online protection and safe usage of Internet and technology.

Orange Group Corporation has also raised awareness regarding environmental issues, global climate change and responsible consumption.

Another example of successful CSR engagement is Vodafone Egypt, which covers a wide range of aspect and activities aimed to benefit the society and the local community including: Education development, Community support programs, Health support programs, Environmental issues \& concerns and waste management.

Vodafone Egypt have also raised awareness and initiated safe driving campaigns, blood donation campaigns, renovation of poverty housing in slums and rural areas etc.

Recently, many organizations have initiated several attempts to integrate CSR into their business strategies. The previously mentioned cases are examples of how organizations are beginning to recognize CSR's vital role for long term success.

\section{Methodology:}

This study's data collection process relied mainly on primary data \& self-administered questionnaires conducted with

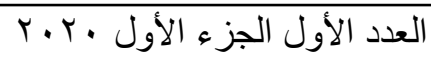
المجلد الحادي عشر 
Corporate Social Responsibility and its impact on Customer Perception \& Loyalty

Dr. Ashraf Saber Kamel

customers consuming products of two multinational corporates with a wide presence in assisting the society and remarkably engaging in CSR programs. The main aim of the questionnaire is to measure the extent to which CSR impacts the company's reputation in general and the consumer behavior in particular.

The other part of our data collection process included a questionnaire conducted with the employees of the previously mentioned corporations, and its aim was to clarify the extent to which engaging in CSR impacts employees in terms of performance and loyalty to the workplace, as well as identifying the impact of engaging in CSR programs on the overall corporate performance.

After obtaining the required data, the numbers were then statistically analyzed using IBM's statistical analysis and processing software "SPSS". This software will serve the study's purpose by analyzing the association \& relationship between the research's variables.

The study's independent variable is engaging and adopting CSR initiatives \& programs. Meanwhile, the study considers two dependent variables; the first dependent variable is customer perception and consumer behavior towards the corporate the implements CSR programs. The second dependent variable is employees' performance \& loyalty towards the organization.

العدد الأول الجزء الأول •r.r

المجلد الحادي عشر 
Corporate Social Responsibility and its impact on Customer Perception \& Loyalty Dr. Ashraf Saber Kame1

To test the accuracy \& validity of the study's hypotheses, the following statistical tools were used: Mean, Anova, standard deviation, and Adjusted $R$ square. These statistical tools will indicate whether there is an association between the independent $\&$ dependent variables or not.

\section{Population \& Sampling:}

The study's data collection process relied on samples of consumers \& employees in the Egyptian Market. These participants are well educated- university graduates who clearly understand the significance of CSR and its impact on the society.

The sample of customers consisted of 50 customers which are users of the two major telecommunications companies in Egypt.

The sample of employees included 35 employees who are hired by reputable 2 different corporates that play an extremely vital role in terms of assisting the society and executing CSR programs.

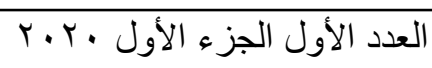
المجلد الحادي عشر 
Corporate Social Responsibility and its impact on Customer Perception \& Loyalty Dr. Ashraf Saber Kamel

\section{Data Collection:}

The following data are the initial results obtained by conducting the survey:

\begin{tabular}{|l|c|c|c|c|c|}
\hline \multicolumn{1}{|c|}{ Statement } & $\begin{array}{c}\text { Strongly } \\
\text { Agree }\end{array}$ & Agree & Moderate & Disagree & $\begin{array}{c}\text { Strongly } \\
\text { Disagree }\end{array}$ \\
\hline $\begin{array}{l}\text { Does A company's } \\
\text { CSR effort affect } \\
\text { your purchasing } \\
\text { decision? }\end{array}$ & 19 & 15 & 5 & 7 & 4 \\
\hline $\begin{array}{l}\text { Does adopting CSR } \\
\text { by companies } \\
\text { increase your loyalty } \\
\text { and trust towards } \\
\text { them? }\end{array}$ & 16 & 16 & 3 & 11 & 4 \\
\hline $\begin{array}{l}\text { Do you believe that } \\
\text { more CSR efforts } \\
\text { improve the } \\
\text { company's } \\
\text { reputation? }\end{array}$ & 18 & 21 & 2 & 7 & 2 \\
\hline $\begin{array}{l}\text { Would you avoid } \\
\text { buying a particular } \\
\text { product/service of a } \\
\text { company due to its } \\
\text { negligence of CSR? }\end{array}$ & 20 & 12 & 5 & 10 & 3 \\
\hline $\begin{array}{l}\text { Do you frequently } \\
\text { experience/perceive } \\
\text { the importance of } \\
\text { Vodafone \& } \\
\text { Orange's CSR } \\
\text { programs? }\end{array}$ & 23 & 11 & 7 & 6 & 3 \\
\hline
\end{tabular}

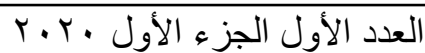
المجلد الحادي عشر 
Corporate Social Responsibility and its impact on Customer Perception \& Loyalty Dr. Ashraf Saber Kamel

The second survey was conducted with 35 employees of Vodafone Egypt \& Orange Egypt, the two corporates with a remarkable presence in adopting CSR.

\begin{tabular}{|l|c|c|c|c|c|}
\hline Statement & $\begin{array}{l}\text { Strongly } \\
\text { Agree }\end{array}$ & Agree & Moderate & Disagree & $\begin{array}{c}\text { Strongly } \\
\text { Disagree }\end{array}$ \\
\hline $\begin{array}{l}\text { Does your } \\
\text { company }\end{array}$ & 12 & 5 & 7 & 2 & 9 \\
$\begin{array}{l}\text { Frequently } \\
\text { announce/make } \\
\text { you aware of its } \\
\text { CSR activities? }\end{array}$ & 9 & 18 & 3 & 4 & 1 \\
\hline $\begin{array}{l}\text { Does your } \\
\text { company's CSR } \\
\text { effort affect your } \\
\text { Performance } \\
\text { Positively? }\end{array}$ & 14 & 10 & 3 & 5 & 3 \\
\hline $\begin{array}{l}\text { Does adopting } \\
\text { CSR by your } \\
\text { company increase } \\
\text { your loyalty and } \\
\text { trust? }\end{array}$ & 13 & 7 & 5 & 8 & 2 \\
\hline $\begin{array}{l}\text { Do you believe } \\
\text { that more CSR } \\
\text { efforts improve } \\
\text { the company's } \\
\text { reputation? }\end{array}$ & 19 & 12 & 2 & 1 & 1 \\
\hline $\begin{array}{l}\text { Would you avoid } \\
\text { working or reject a } \\
\text { job offer of a } \\
\text { company due to its } \\
\text { negligence of } \\
\text { CSR? }\end{array}$ & 13 & & & & \\
\hline
\end{tabular}

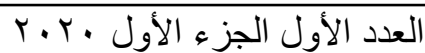
المجلد الحادي عشر 
Corporate Social Responsibility and its impact on Customer Perception \& Loyalty Dr. Ashraf Saber Kamel

\section{Data Analysis:}

Analysis of Variance, also known as "Anova" is a parametric statistical method/technique to compare several data sets. It is best applied whenever there are more than 2 populations or samples present that are meant to be compared.

The following results were obtained after conducting the analysis of variance test ANOVA via SPSS:

\section{Summary of Data}

\begin{tabular}{|l|c|c|c|c|c|c|}
\hline \multirow{2}{*}{} & \multicolumn{7}{|l}{ Groups } \\
\cline { 2 - 7 } & 1 & 2 & 3 & 4 & 5 & Total \\
\hline $\mathbf{N}$ & 5 & 5 & 5 & 5 & 5 & 25 \\
\hline$\sum \mathbf{X}$ & 96 & 75 & 22 & 41 & 16 & 250 \\
\hline Mean & 19.2 & 15 & 4.4 & 8.2 & 3.2 & 10 \\
\hline$\sum \mathbf{X}^{\mathbf{2}}$ & 1870 & 1187 & 112 & 355 & 54 & 3578 \\
\hline Std. Dev. & 2.5884 & 3.937 & 1.9494 & 2.1679 & 0.8367 & 6.702 \\
\hline
\end{tabular}

\begin{tabular}{|l|c|c|c|c|}
\hline \multicolumn{5}{|c|}{ Breakdown of results } \\
\hline Source & $\begin{array}{l}\text { Sum of } \\
\text { squares }\end{array}$ & df & MS & \\
\hline $\begin{array}{l}\text { Between- } \\
\text { Treatments }\end{array}$ & 952.4 & 4 & 238.1 & F= 37.91401 \\
\hline $\begin{array}{l}\text { Within- } \\
\text { Treatments }\end{array}$ & 125.6 & 20 & 6.28 & \\
\hline Total & 1078 & 24 & & \\
\hline
\end{tabular}

The f-ratio value is 37.9140 , the $p$-value is $<0.00001$

The result is significant at $\mathrm{p}<0.05$

العدد الأول الجزء الأول •r.r المجلد الحادي عشر 
Corporate Social Responsibility and its impact on Customer Perception \& Loyalty Dr. Ashraf Saber Kamel

The previous results indicate a significant association between engaging in CSR activities and customer perception. Therefore, the study's hypothesis H1 has been affirmed and substantiated. This means that customer perception \& behavior towards the company is clearly affected by the company's role in CSR.

\section{Summary of Data}

\begin{tabular}{|l|c|c|c|c|c|c|}
\hline \multirow{2}{*}{} & \multicolumn{7}{|l}{ Groups } & \multicolumn{2}{l|}{} \\
\cline { 2 - 7 } & 1 & 2 & 3 & 4 & 5 & Total \\
\hline $\mathbf{N}$ & 5 & 5 & 5 & 5 & 5 & 25 \\
\hline$\sum \mathbf{X}$ & 67 & 52 & 20 & 20 & 16 & 175 \\
\hline Mean & 13.4 & 10.4 & 4 & 4 & 3.2 & 7 \\
\hline$\sum \mathbf{X}^{\mathbf{2}}$ & 951 & 642 & 96 & 110 & 96 & 1895 \\
\hline Std. Dev. & 3.6469 & 5.0299 & 2 & 2.7386 & 3.3466 & 5.2836 \\
\hline
\end{tabular}

\begin{tabular}{|l|c|c|c|c|}
\hline \multicolumn{5}{|c|}{ Breakdown of results } \\
\hline Source & $\begin{array}{l}\text { Sum of } \\
\text { squares }\end{array}$ & df & MS & \\
\hline $\begin{array}{l}\text { Between- } \\
\text { Treatments }\end{array}$ & 424.8 & 4 & 106.2 & F= 8.66232 \\
\hline $\begin{array}{l}\text { Within- } \\
\text { Treatments }\end{array}$ & 245.2 & 20 & 12.26 & \\
\hline Total & 670 & 24 & & \\
\hline
\end{tabular}

The f-ratio value is 8.66232 , the $\mathrm{p}$-value is $<0.000316$

The result is significant at $\mathrm{p}<0.05$

العدد الأول الجزء الأول •.r.r المجلد الحادي عشر 
Corporate Social Responsibility and its impact on Customer Perception \& Loyalty Dr. Ashraf Saber Kame1

Based on the results obtained via the statistical analysis, there is an obvious association between engaging in CSR and more effective employee performance as well as more loyalty from the employees towards the organization. This supports the assumption of the study's hypothesis $\mathrm{H} 2$ and confirms it.

\section{Conclusion:}

Based on our data analysis, it's obvious \& clear that CSR has a tremendous \& significant impact on the consumer's behavior and attitude towards the company, in addition to the strong relationships established between the company and its employees due to implementing CSR programs. Most employees seek joining organizations that play a remarkable role $\&$ are capable of making changes and positively impacting the society.

It has been substantiated that consumers prefer to purchase from $\&$ deal with ethically responsible enterprises that aid the society in which they are operating in.

In addition, most employees are seeking to join organizations and enterprises that are socially liable and willing to add to their ethical \& moral value.

Eventually, Corporates that are actually transparent and have a higher sense of responsibility towards local \& global concerns are more likely to attract and retain highly qualified \& talented employees.

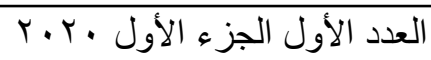

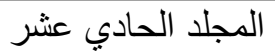


Corporate Social Responsibility and its impact on Customer Perception \& Loyalty Dr. Ashraf Saber Kamel

\section{References}

1. https://www.investopedia.com/terms/c/corp-socialresponsibility.asp Chen, James retrieved 11th February 2019

2. https://www.unido.org/our-focus/advancing-economic competitiveness/competitive-trade-capacities-and-corporateresponsibility/corporate-social-responsibility-marketintegration/what-csr

3. Broomhill, R. (2007). Corporate social responsibility: key issues and debates School of Political and International Studies, Flinders University Don Dunstan Foundation Papers Series, No. 1.

4. Carroll, A. B. \& Shabana, K. M. (2010). The business case for corporate social responsibility: A review of concepts, research and practice.j International Journal of Management Reviews, 85- 105, DOI: 10.1111/j.1468-2370.2009.00275.xmr

5. Porter, M. E., \& Kramer, M. R. (2006). Strategy and society. The link between competitive advantage and corporate social responsibility. Harvard Business Review, 12: 78-92.

6. Rangan, K., Chase, L. A., \& Karim, S. (2012). Why every company needs a CSR strategy and how to build it. Harvard Business School: Working Paper 12-088

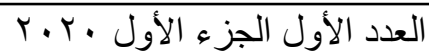
المجلد الحادي عشر 